\title{
Personal resilience and coping with implications for work. Part I: A review
}

\author{
Valerie Rice ${ }^{\mathrm{a}, *}$ and Baoxia Liu ${ }^{\mathrm{b}}$ \\ a Army Research Laboratory, Human Research \& Engineering Directorate, Army Medical Department Field \\ Element, Ft. Sam Houston, San Antonio, TX, USA \\ ${ }^{\mathrm{b}}$ DCS Corporation, Alexandria, VA, USA
}

Received 8 May 2015

Accepted 3 April 2016

\begin{abstract}
.
BACKGROUND: Interest in resilience has increased in recent years. The U.S. military focus is on personal health and adaptation following exposure to battle, while the civilian interest centers on adjustments subsequent to disastrous events. Coping skills are also relevant, yet the relationships between coping and resilience are unclear.

OBJECTIVE: This brief review examines personal resilience and individual coping strategies, exploring definitions of each, along with their potential relationships to one another. Their potential contributions within a work setting are described.

METHODS: A literature review was conducted using search terms of resilience, resiliency, personal resilience, coping and resilient coping.

RESULTS: Coping refers to one's using purposeful actions to handle life situations. Coping techniques can be functional or dysfunctional and the situations one copes with may be acute or long term, severe or minor. Resilience refers to positive and functional handling of oneself and ones' life, referring to the ability to recover, recuperate, and regenerate following tragic events.

CONCLUSIONS: While coping and resilience are related to one another, they are distinct concepts. Positive coping techniques may contribute to resilience. However, which coping techniques improve resilience, and in what circumstances, are questions for future research.
\end{abstract}

Keywords: Trauma, active duty, veteran, training

\section{Introduction}

Increasing interest in personal resilience has followed catastrophic events and environmental disasters, such as U.S. troop involvement in Iraq and Afghanistan; the 9/11 attack in New York City, NY; recent bombings in Paris; shootings in San Bernardino, CA; and extreme storms, earthquakes,

\footnotetext{
*Address for correspondence: Valerie Rice, Army Research Laboratory HRED AMEDD Field Element, 3250 Koehler Rd, Suite 1099, Ft. Sam Houston, San Antonio, TX 78234-7731, USA. Tel.: +1 210221 2007; E-mail: valerie.j.rice.civ@mail.mil.
}

and floods. Articles abound regarding individuals, businesses, schools, communities, and countries seeking to increase their resilience. Individuals and groups want to improve their ability to withstand, recover, return, and thrive. That is, they want to withstand adversity, recover from calamity, return to normalcy, and continue to grow and prosper, while simultaneously acknowledging the severity of the situation they have experienced.

In the open literature, it is not always clear whether the constructs of resilience and coping are the same, similar, different from one another, how they 
might overlap, or whether one "feeds into" the other. Depending on which articles one reads, coping may be considered a subcomponent of resilience or vice versa; positive coping may refer to the actions taken by a resilient person; or the concepts within each may differ from one another.

Within the U.S. military, the stress of combat is considered an occupational hazard [1] and can be debilitating [2]. Soldier resilience is of utmost importance [3] and U.S. soldiers receive resiliency training (see http://www.army.mil/readyandresilient/). However, specific methods of coping are not necessarily taught as part of resilience training and the relationship between ones' coping strategies and their resilience is not well understood.

Understanding coping and resilience will benefit both the civilian and military sectors and impact training provided in each. This brief review examines personal resilience and individual coping strategies, exploring each and their potential relationship to one another, and probing their potential contributions within a work setting.

\section{Literature review}

\subsection{Resilience}

Resilience is the ability to encounter and move through significant hardship [4], while continuing to function effectively in basic life tasks, such as continuing to work, interacting with and maintaining relationships with friends and relatives, and remaining interested and involved in leisure pursuits. For individuals, this process of positive adaptation [5] includes maintaining a "stable trajectory of healthy functioning across time" [6] (p. 21).

While the definition of resilience refers to moving through and recovering from adversity, this does not imply that resilience is short-lived - occurring only in the face of a singular hardship. Some research has shown that individuals who are resilient tend to show healthy, long-term psychological functioning [7]. Other findings show that resilience is not predictably stable over time, as resilience is influenced by internal and external factors and life experiences [8]. Resilience is also differentially defined and influenced by culture [9]. Thus, resilience is an on-going process $[10,11]$ and individuals may be more resilient during one period of their lives than another. Rather than being a singular quality that one is born with, resilience develops over time and is influenced by perceptions, culture, family, experiences, and training [12-16].

The characteristics described as associated with resilience are similar among those who study and write about the topic (Table 1). As an example, Antonovsky [32, 33] wrote of Sense of Coherence (SOC) as a conceptual explanation of overcoming adversity. SOC contains three components: comprehensibility, manageability and meaningfulness. Comprehensibility refers to recognizing both the world and the hardship one is facing as explicable. Manageability suggests a conviction regarding the capability to handle the situation(s) oneself or with the help of others. Meaningfulness denotes identifying sense and value in overcoming hardship. Similar characteristics, with slightly different names and/or descriptions can be seen in Table 1. Meaningfulness as described within the SOC framework is similar to 'meaning making', and manageability might include concepts of a 'can do' attitude, commitment and active involvement, mastery and problem solving.

The characteristics associated with resilience may exist prior to facing adversity, and as such may be considered to enhance or promote resilience, or perhaps be preventative in nature. However, according to some researchers, these same characteristics may develop after exposure to trauma, as part of a post-traumatic growth (PTG) process [22, 34]. Posttraumatic growth refers to the process during which one's struggles lead to positive psychological development, often deeply meaningful for the individual. However, post-traumatic growth does not occur for everyone [22,34]. It is not known for certain whether those who were considered to be resilient before exposure to trauma or tragedy are more likely to benefit from PTG than those who were not resilient [34], and research is ongoing in this area [35].

Of particular relevance to businesses, companies, and the military are findings that resilience is related to workplace performance [13, 15, 17, 36-38]. In a workplace context, resilience has been re-defined as the "positive psychological capacity to rebound, or 'bounce back' from adversity, uncertainty, conflict, failure or even positive change, progress, and increased responsibility" [39] (p.702). Note that resilience is mentioned in terms of 'bouncing back' from both negative and positive situations and experiences in this context. Individuals who are more resilient are considered to be more adaptive within the perpetually changing workplace $[40,41]$ and may contribute to a more resilient organization. Resilience is positively related to job satisfaction, work happi- 
Table 1

Characteristics of resilience

- Accept reality/face facts - accept what they cannot change [17-21]

- Appreciation of life/gratitude $[19,22]$

- "Can Do" attitude - initiative taking and tenacity [23-25]

- Pragmatic coping "whatever it takes"

- Cognitive/Brain Fitness [19, 21, 26, 27]

$\circ$ Ability to attend on demand, including reducing distractions

- Cognitive reappraisal

- Cognitive flexibility

- Commitment \& active involvement [14, 28]

- Confront (face) their fears [19]

- Control - a determination to influence outcomes [14, 28, 29]

- Emotional Fitness [19, 21]

- Self-regulation (adjusting emotions \& behavior to fit internal and external social constraints)

- Stability

○ Take responsibility for their own emotional well being

o Emotional flexibility

- Flexibility - ability to improvise, and possess a 'challenge orientation' [14, 17, 29, 24]

- Hardiness [24]

- Humor $[19,20,27]$

- Mastery - steering oneself in a goal-directed manner and experiencing success en route [21]

- Meaning making - making meaningful sense of hardship and looking for opportunity in adversity [17, 19, 23]

- Moral Imperative/Moral Compass [19]

○ Altruism/give back

- Optimism, hope, seeing new possibilities while remaining realistic [19, 22, 24, 30]

$\circ$ Dispositional optimism

- Personal Strength [22]

- Physical Fitness (\& exercise) [19, 21, 30],

- Problem solving [19, 20, 31]

- Active

- Approach based

- Problem-focused/goal directed (constructive use of resources to identify and act on solutions)

- Religion/Spirituality [19, 22]

- Role Models - have and imitate sturdy role models [19]

- Self-care [19]

$\circ$ They take care of themselves, health, well-being and fitness

- Physical, Brain/Cognitive, Emotional

- Social Support [19, 20, 22, 25, 27, 30]

- Constructive Attachments (bonding with supportive others)

$\circ$ Being able to ask for, receive, and use social support

- Relating to others

$\circ$ Reaching out to other survivors

NOTE: This is not an all-inclusive list, as many other authors and papers have contributed to this body of knowledge.

ness and organizational commitment [37]. Personal resilience can contribute to employees' commitment to change by engendering positive emotions during organizational transformation [40]. Table 2 shows the components of resilience from one measure of resilience, the Resilience Scale [42] and their potential impact on the workplace. Developing work-related personal resilience does not happen in a vocational vacuum, as one's family [43, 44] and other factors influence resilience building. Moreover, individual resilience is only one part of developing team, organization, or community resilience [45].

Studies have discussed the factors that promote resilience beyond the individual level, such as within families, organizations, or communities [21, 46]. In a team setting, leaders' confidence, intellectual stimulation, individualized consideration, and contingent award systems have been positively associated with subordinate resilience [36]. In a workplace, support from peers, team members, managers, and company culture are all factors that contribute to employee resilience [47]. Examples of workplace or company resilience, both of individuals and of a company as a whole, are exemplified by the recovery of Reuters America [48] and Southwest Airlines [49] following the terrorist attacks in the U.S. on $9 / 11$. Kimhi and Shamai [50] describe community resilience as containing three elements: resistance, recovery, and creativity. Creativity addresses the community's ability to originate and recreate opportunities for growth 
Table 2

Five essential components of the Resilience Scale and their possible work relevance*

\begin{tabular}{|c|c|}
\hline Survey Items & Work relevance \\
\hline $\begin{array}{l}\text { Self-Reliance } \\
\text { - I usually manage one way or another } \\
\text { - I feel that I can handle many things at a } \\
\text { time } \\
\text { - I can get through difficult times because } \\
\text { I've experienced difficulty before } \\
\text { - In an emergency, I'm someone people } \\
\text { can generally rely on } \\
\text { - When I'm in a difficult situation, I can } \\
\text { usually find my way out of it }\end{array}$ & $\begin{array}{l}\text { - "Can do" attitude } \\
\text { - Able to supervise or participate in multiple } \\
\text { projects at once } \\
\text { - Self-confidence about handling work } \\
\text { - Being reflective of one's capabilities and } \\
\text { limitations at work } \\
\text { - Learns from past experiences, building } \\
\text { problem-solving skills } \\
\text { - Trustworthy - has "co-workers back" } \\
\text { - Innovative with problem solving }\end{array}$ \\
\hline $\begin{array}{l}\text { Meaning } \\
\text { - I feel proud that I have accomplished } \\
\text { things in life } \\
\text { - I keep interested in things } \\
\text { - My life has meaning }\end{array}$ & $\begin{array}{l}\text { - Takes pride in work and achievements } \\
\text { - Open-minded } \\
\text { - Understands the purpose of one's work and } \\
\text { how it benefits the society }\end{array}$ \\
\hline $\begin{array}{l}\text { Equanimity } \\
\text { - I usually take things in stride } \\
\text { - I can usually find something to laugh } \\
\text { about }\end{array}$ & $\begin{array}{l}\text { - Can regulate emotions } \\
\text { - Adaptive, flexible } \\
\text { - Optimistic, uses humor } \\
\text { - Uses positive emotions to deal with stress }\end{array}$ \\
\hline $\begin{array}{l}\text { Perseverance } \\
\text { - I am determined } \\
\text { - I have self-discipline }\end{array}$ & $\begin{array}{l}\text { - Sets goals and is persistent in achieving } \\
\text { them, motivated } \\
\text { - Can manage own time, stay on task }\end{array}$ \\
\hline $\begin{array}{l}\text { - My belief in myself gets me through hard } \\
\text { times }\end{array}$ & $\begin{array}{l}\text { - Offers compassion to oneself, takes care of } \\
\text { one's needs, good at working alone, may } \\
\text { decrease burnout } \\
\text { - Aware of own unique contribution to the } \\
\text { work place } \\
\text { - Confident in one's own skills and abilities }\end{array}$ \\
\hline
\end{tabular}

*It might also be expected that an individual who is more resilient would have a more balanced perspective of their work and a better work-life balance.

and revival after encountering disaster [51]. Amit and Fleischer [52] have published on the concept of national resilience in terms of sustainability and strength. National resilience is thought to be influenced by patriotism, optimism, social integration and trust [53].

\subsection{Coping}

Coping per se is not typically considered a characteristic of resilience (Table 1). Coping has been described as "constantly changing cognitive and behavioral efforts to manage specific external and/or internal demands that are appraised as taxing or exceeding the resources of the person" [54] (p. 141). These 'demands' vary from day-to-day problems [31, 54-56] to serious trauma [57]. While everyone uses coping skills, not everyone who uses coping skills is resilient, as explained in the following paragraphs.

Not all coping approaches are helpful. Unlike resilience, which is defined as positive adaptation to change, coping techniques may be helpful or harmful in regard to both the immediate situation, as well as to the psychological health of the individual. One's understandings of life situations and their coping responses can either result in additional suffering or contribute to assuaging the problem [58]. Two positive coping styles are problem-focused coping and emotion-focused coping [59-62]. For example, the COPE Inventory (Coping Operations Preference Enquiry) identifies three primary coping styles: problem-focused coping, emotion-focused coping, and dysfunctional coping [61]. These categories are further divided into 14 subcategories. These subcategories are described, and their likely 
relationships to work settings are shown in Table 3. For example, active coping is a type of problemfocused coping, referring to one's attempts to regulate or control the stressor. Active coping, along with good mental and physical health, is related to successful aging and a person's ability to work [62]. Meanwhile, another coping style - avoidant coping - is a technique in which one attempts to avoid the stressor and its consequences and it is negatively related to work ability [63]. Successful coping is considered to be adaptive and can include self-reflection, planning, dynamism and multidimensional thinking $[64,65]$. One's coping strategy can ultimately influence their physical $[66,67]$ and emotional health [68].

The development of appropriate coping mechanisms is thought to be part of a healthy growth process and fundamental to social-emotional functioning [68] and overall well-being [68-70]. Like resilience, coping changes developmentally and experientially across one's lifespan [71]. Also, like resilience, coping is related to one's perceptions. Individuals' coping abilities are instrumental in their appraisal of situations and key in their adaptation [69, 72]. Again, coping refers to encounters in everyday life, as well as with great distress, while resilience refers to dealing with adversity and trauma rather than with commonplace circumstances.

Coping strategies can be learned and therefore can be trained. In an investigation of cognitive-behavioral training of Australian Army recruits, the intervention group received specific instruction on coping strategies [73]. At the end of basic training, recruits receiving the instruction reported less use of negative coping strategies, more positive states of mind, and less psychological distress than the control group [73].

Ineffective coping can also be learned, potentially developing through repetition [73]. That is, if a person experiences an untoward event and responds in a protective, yet ineffective manner a few times, then a conditioned response can begin to develop. In the future, a situational trigger is likely to yield similar results. This conditioned response may need to be deconditioned. Ledoux and Gorman [74] suggested those with Post Traumatic Stress Disorder have incurred such persistent emotional conditioning in the form of "memories that seize control of mental life and behavior" (p. 1955), but they submit these responses can be rerouted through the learning of adaptive coping. Organizations may need to train employees on how not to use dysfunctional coping during challenging situations, instead engaging in positive coping strategies [66].

Van den Heuvel and colleagues suggest that promoting positive coping styles and health can sustain employability [63]. However, individuals high in active coping, but without an option for having control over their work, can become frustrated and emotionally exhausted [75]. Coping skills have been found to be important influences on work engagement in a wide range of fields such as police recruits [76] and among nurses and midwives [77]. More specifically, problem-focused coping, low use of avoidance coping, and low use of venting of emotions (as a coping strategy) predicted work engagement among nurses [78]. It can be seen from these examples that while coping skills are related to one's abilities in the workplace, the relationship can be complex and differ per occupation or set of job requirements.

\subsection{Resilience and coping}

While information on the relationship between resilience and coping can seem ambiguous, according to Glennie [57] (p. 169), "Although coping and resilience are related constructs, they are distinct in that coping refers to a wide set of skills and purposeful responses to stress, whereas resilience refers to positive adaptation in response to serious adversity." Coping refers to actions taken to deal with any type of stressors (large or small, daily or long-term), while resilience refers to the result of positive coping strategies following significant tragic events. Coping skills can be positive, negative, or dysfunctional, thus not necessarily leading to improved functioning, while resilience denotes beneficial adaptation only. A number of questions arise from this brief review, some of which will be addressed in the recommendations.

\section{Recommendations}

The recommendations from this review include use of the terms resilience and coping in publications, as well as suggestions for future research.

Publications on resilience and coping should refrain from using the terms interchangeably, as this confuses the issues for readers. For example, some articles refer to their outcome measurements as assessing both resilience and coping; however in reading the articles, testing includes coping scales, interpersonal skills, social impact measures, or interviews, but no specific measures of resilience 
Table 3

Brief COPE subscales, definitions and work relevance

\begin{tabular}{|c|c|c|}
\hline Subscales & Definitions & Work relevance \\
\hline \multicolumn{3}{|l|}{ Emotion-Focused Coping } \\
\hline Acceptance & $\begin{array}{l}\text { Accepting the reality that the stressor } \\
\text { happened and learning to live with it }\end{array}$ & $\begin{array}{l}\text { Accepts work place situations that are out of } \\
\text { one's control and focuses on examining } \\
\text { possible solutions }\end{array}$ \\
\hline Emotional Support & Getting moral support from others & $\begin{array}{l}\text { Willing to receive or seek support, sympathy } \\
\text { from coworkers }\end{array}$ \\
\hline Humor & Using humor and making fun of the stressor & $\begin{array}{l}\text { Humor can engender positive emotions and } \\
\text { laughter, buffer against depression, and } \\
\text { reduce stress, and therefore yield a more } \\
\text { positive workplace }\end{array}$ \\
\hline Positive Reframing & $\begin{array}{l}\text { Viewing a stressor in positive terms that } \\
\text { should lead to active, problem-focused } \\
\text { coping }\end{array}$ & $\begin{array}{l}\text { Seeing things in positive perspectives and } \\
\text { promoting a positive working environment }\end{array}$ \\
\hline Religion & $\begin{array}{l}\text { Using one's religion as a source of emotional } \\
\text { support and an active coping }\end{array}$ & $\begin{array}{l}\text { Religious beliefs can encourage a positive } \\
\text { attitude, positive reinterpretation, and } \\
\text { individual growth in workplace }\end{array}$ \\
\hline \multicolumn{3}{|l|}{ Problem-Focused Strategies } \\
\hline Active Coping & $\begin{array}{l}\text { Taking steps to remove or ameliorate the } \\
\text { stressor }\end{array}$ & Takes active steps to solve problems \\
\hline & & Takes the initiative \\
\hline Planning & $\begin{array}{l}\text { Thinking out a systematic method to cope } \\
\text { with a stressor }\end{array}$ & $\begin{array}{l}\text { Thoughtful at work with decision making or } \\
\text { actions } \\
\text { Systematic in approach }\end{array}$ \\
\hline Instrumental Support & $\begin{array}{l}\text { Asking for help and advice from others, } \\
\text { seeking advice }\end{array}$ & $\begin{array}{l}\text { Willing to ask for help when needed, good at } \\
\text { delegation of tasks }\end{array}$ \\
\hline \multicolumn{3}{|c|}{ Dysfunctional Coping Strategies } \\
\hline Denial & Refusal to believe the stressor exists & $\begin{array}{l}\text { Deny real work-related problems, and if } \\
\text { denial cannot be used, one's stress may } \\
\text { increase }\end{array}$ \\
\hline Self-Distraction & $\begin{array}{l}\text { Focusing on other things to take one's mind } \\
\text { off the stressor }\end{array}$ & $\begin{array}{l}\text { May put work effort on those projects that } \\
\text { are less stressful or be less productive } \\
\text { during stress }\end{array}$ \\
\hline Substance Abuse & Use of alcohol or drugs & $\begin{array}{l}\text { May have absences from work or difficulty } \\
\text { performing duties }\end{array}$ \\
\hline Behavioral Disengagement & Giving up trying to manage the stress & $\begin{array}{l}\text { Separate themselves from situations they } \\
\text { perceive as outside their control or beyond } \\
\text { their abilities by not fully participating, } \\
\text { refusing involvement, or giving up }\end{array}$ \\
\hline Self-Blame & $\begin{array}{l}\text { Criticizing one's self, blaming one's self for } \\
\text { what happened }\end{array}$ & $\begin{array}{l}\text { Blame themselves for perceived } \\
\text { work-related failures, possibly creating a } \\
\text { blaming and depressed atmosphere for } \\
\text { themselves and others in the workplace }\end{array}$ \\
\hline Venting & $\begin{array}{l}\text { Focusing on and verbalizing negative } \\
\text { feelings }\end{array}$ & $\begin{array}{l}\text { Consistently focus on distress negatively. } \\
\text { Can create an unhappy, dissatisfied work } \\
\text { atmosphere for self and others. May } \\
\text { distract workforce from active, positive } \\
\text { problem solving }\end{array}$ \\
\hline
\end{tabular}

$[79,80]$. Thus, leaving readers to the idea that coping and resilience are the same. The reverse can also occur where authors refer to their measures as including both resilience and coping, yet their measurement section contains characteristics associated with resilience (such as the SOC), symptoms of stress, and exposure to war, but no measures of coping [81]. While such articles provide valuable information regarding their research, using the terms interchangeably is misleading.
Research recommendations include:

- Investigating the relationship between coping and resiliency.

- Identifying the coping mechanisms of highly resilient vs. less resilient individuals.

- Detecting whether the coping mechanisms of highly resilient individuals differ per environment or job (such as military, business, police, etc.). 
- Exploring whether training in specific coping skills contributes to overall resiliency.

- Developing a resilience questionnaire or measurement for military personnel to help the placement for specific military positions.

- Investigating long term outcomes to determine whether training in coping skills or resiliency are preventative.

\section{Conclusions}

Resilience and coping are related to one another, and yet remain distinct concepts. Understanding both is important to assisting individuals deal with adversity, teaching resiliency, and conducting research on resilience. Research opportunities abound for exploring each and for examining the associations between the two concepts.

\section{Acknowledgments}

This research was supported by the U.S. Army Research Program Office.

\section{Disclaimer}

The views expressed in this article are those of the authors and do not reflect the official policy or position of the Department of the Army, Department of Defense, or the U.S. Government.

\section{Conflict of interest}

The authors have no conflict of interest to report.

\section{References}

[1] Gerardi SM. Part I. Work hardening for warrior: Occupational therapy for combat stress casualties.Work: A Journal of Prevention, Assessment, and Rehabilitation 1999;13(3):185-95.

[2] Rice VJ, Gerardi SM. Part II. Work hardening for warriors: Training military Occupational Therapy professionals in the management of combat stress casualties. Work: A Journal of Prevention, Assessment, and Rehabilitation 1999;13(3):197-209.

[3] Rice VJ, Overby C, Boykin G, Jeter A, Villarreal J. How Do I Handle My Life Now? Coping and the Post Traumatic Stress Disorder Checklist-Military Version. In Proceedings of the Human Factors and Ergonomics Society Annual Meeting;
Santa Monica, CA: Human Factors and Ergonomics Society and SAGE Publications 2014;58(1):1252-56.

[4] Masten AS, Cutuli JJ, Herbers JE, Reed MJ. Resilience in development. In: Lopez SJ, Snyder CR, editors. Oxford handbook of positive psychology. 2nd ed., 117-31. New York, NY: Oxford University Press; 2009.

[5] Norris FH, Stevens SP, Pfefferbaum B, Wyche KF, Pfefferbaum RL. Community resilience as a metaphor, theory, set of capacities, and strategy for disaster readiness. American Journal of Community Psychology 2008;41(1-2): 127-50.

[6] Bonanno, GA. Loss, trauma, and human resilience: Have we underestimated the human capacity to thrive after extremely aversive events? American Psychologist 2004; 59 (1):20-8.

[7] Werner EE. Risk, resilience, and recovery: Perspectives from the Kauai Longitudinal Study. Development and psychopathology 1993;5(04):503-15.

[8] Van Kessel G. The ability of older people to overcome adversity: A review of the resilience concept. Geriatric Nursing 2013;34(2):122-7.

[9] Didkowsky N, Ungar M, Liebenberg L. Using visual methods to capture embedded processes of resilience for youth across cultures and contexts. Journal of the Canadian Academy of Child and Adolescent Psychiatry 2010;19(1):12-8.

[10] Siebert A. Developing a highly resilient, change proficient work force. 2002. Available from: http://resiliencycenter. com/developing-a-highly-resilient-change-proficient-work -force/

[11] Windle G, Bennett KM, Noyes J. A methodological review of resilience measurement scales. Health and Quality of Life Outcomes 2011;9(8):1-18.

[12] Connor KM, Zhang W. Resilience: Determinants, measurement, and treatment responsiveness. CNS Spectrums 2006;11(S12):5-12.

[13] Luthans F, Vogelgesang GR, Lester PB. Developing the psychological capital of resiliency. Human Resource Development Review 2006;5(1):25-44.

[14] Maddi SR, Khoshaba DM. Resilience at work: How to succeed no matter what life throws at you. New York, NY: AMACOM a Division of the American Management Association; 2005.

[15] Waite PJ, Richardson GE. Determining the efficacy of resiliency training in the work site. Journal of Allied Health 2004;33(3):178-83.

[16] Steinhardt M, Dolbier C. Evaluation of a resilience intervention to enhance coping strategies and protective factors and decrease symptomatology. Journal of American College Health 2008;56(4):445-53.

[17] Coutu DL. How resilience works. Harvard Business Review 2002;80(3):46-55.

[18] Siebert A. The Resiliency Advantage: Master Change, Thrive Under Pressure, and Bounce Back from Setbacks: Easyread Super Large 18pt Edition. ReadHowYouWant. Com; 2008.

[19] Southwick SM, Charney DS. Resilience: The science of mastering life's greatest challenges. New York: Cambridge University Press; 2012.

[20] White B, Driver S, Warren AM. Considering resilience in the rehabilitation of people with traumatic disabilities. Rehabilitation Psychology 2008;53(1):9-17.

[21] Meredith LS, Sherbourne CD, Gaillot SJ. Promoting psychological resilience in the US military. Santa Monica, CA: Rand Corporation; 2011. 
[22] Tedeschi RG, Calhoun LG. Trauma and transformation: Growing in the aftermath of suffering. Thousand Oaks, CA: Sage; 1995.

[23] Walsh F. A family resilience framework: Innovative practice applications. Family relations 2002;51(2):130-7.

[24] Westphal M, Bonanno GA. Posttraumatic growth and resilience to trauma: Different sides of the same coin or different coins? Applied Psychology 2007;56(3):417-27.

[25] Friborg O, Barlaug D, Martinussen M, Rosenvinge JH, Hjemdal O. Resilience in relation to personality and intelligence. International Journal of Methods in Psychiatric Research 2005;14(1):29-42.

[26] Troy AS, Mauss IB. Resilience in the face of stress: Emotion regulation as a protective factor. In Resilience and mental health: Challenges across the lifespan. Edited by Steven M. Southwick, Brett T. Litz, Dennis Charney, and Matthey J. Friedman. New York: Cambridge University Press 2011;3044.

[27] Earvolino-Ramirez M. Resilience: A concept analysis. Nursing Forum 2007;42(2):73-82.

[28] Kobasa SC. Stressful life events, personality, and health: An inquiry into hardiness. Journal of Personality and Social Psychology 1979;37(1):1-11.

[29] Campbell D, Campbell K, Ness J. Resilience through leadership. In: Lukey BJ, Tepe V. Editors. Biobehavioral resilience to stress. Boca Raton, FL: CRC Press 2008; 57-88.

[30] Southwick SM, Ozbay F, Charney DS, McEwen BS. Adaptation to stress and psychobiological mechanisms of resilience. In: Lukey BJ, Tepe V. Editors. Biobehavioral resilience to stress. Boca Raton, FL: CRC Press 2008;92108.

[31] Sharkansky EJ, King DW, King LA, Wolfe J, Erickson DJ, Stokes LR. Coping with Gulf War combat stress: Mediating and moderating effects. Journal of Abnormal Psychology 2000;109:188-97.

[32] Antonovsky A. Health, stress, and coping. San Francisco, CA: Jossey-Bass; 1979.

[33] Antonovsky A. Unraveling the mystery of health: How people manage stress and stay well. San Francisco, CA: Jossey-Bass; 1987.

[34] Calhoun LG, Tedeschi RG. Handbook of Posttraumatic Growth. New York: Taylor \& Francis Group, Psychology Press; 2006.

[35] Park N, Peterson C. Characterizing resilience and growth among soldiers: A trajectory study. [Internet] Ann Arbor, MI: University of Michigan; 2012. Available from http://www.dtic.mil/dtic/tr/fulltext/u2/a562181.pdf

[36] Harland L, Harrison W, Jones JR, Reiter-Palmon R. Leadership behaviors and subordinate resilience. Journal of Leadership \& Organizational Studies 2005;11(2):2-14.

[37] Youssef CM, Luthans F. Positive organizational behavior in the workplace the impact of hope, optimism, and resilience. Journal of Management 2007;33(5):774-800.

[38] Zunz S. Resiliency and burnout: Protective factors for human service managers. Administration in Social Work 1998;22(3):39-54.

[39] Luthans F. The need for and meaning of positive organizational behavior. Journal of Organizational Behavior 2002;23(6):695-706.

[40] Shin J, Taylor MS, Seo MG. Resources for change: The relationships of organizational inducements and psychological resilience to employees' attitudes and behaviors toward organizational change. Academy of Management Journal 2012;55(3):727-48.
[41] Tugade MM, Fredrickson BL. Resilient individuals use positive emotions to bounce back from negative emotional experiences. Journal of Personality and Social Psychology 2004;86(2):320-33.

[42] Wagnild GM. The Resilience Scale User's Guide: For the US English Version of the Resilience Scale and the 14-item Resilience Scale (RS-14) (version 3.2). Guinn PE, editor. Worden: Montana. Resilience center; 2011.

[43] Huebner AJ. Advice to the therapists working with military families. National Council on Family Relations [Internet]. 2013. Available from https://www.ncfr.org/ncfrreport/focus/military-families/advice-therapists

[44] Russo TJ, Fallon MA. Coping with Stress: Supporting the Needs of Military Families and Their Children. Early Childhood Education Journal 2014;1-10.

[45] Kimhi S, Eshel Y. Individual and Public Resilience and Coping With Long-Term Outcomes of War1. Journal of Applied Biobehavioral Research 2009;14(2):70-89.

[46] Kirmayer LJ, Dandeneau S, Marshall E, Phillips MK, Williamson KJ. Rethinking resilience from indigenous perspectives. Canadian Journal of Psychiatry. Revue Canadienne de Psychiatrie 2011;56(2):84-91.

[47] Bardoel EA, Pettit TM, De Cieri H, McMillan L. Employee resilience: An emerging challenge for HRM. Asia Pacific Journal of Human Resources 2014;52(3):279-97.

[48] Dutton JE, Quinn R, Pasick R. The Heart of Reuters - Part A and Part B. Ann Arbor, Michigan: Globalens; 2010.

[49] Visser C. Organizational resilience in times of crisis. 2005. Available from http://articlescoertvisser.blogspot. com.au/2007/11/organizational-resilience-in-times-of.html

[50] Kimhi S, Shamai M. Community resilience and the impact of stress: Adult response to Israel's withdrawal from Lebanon. Journal of Community Psychology 2004;32(4):439-51.

[51] Kulig JC. Community resiliency: The potential for community health nursing theory development. Public Health Nursing 2000;17(5):374-85.

[52] Amit K, Fleischer N. Between resilience and social capital. In: The Concept of Social Resilience. Edited by Friedland N, Arian A, Kirschnbaum A, et al. Haifa, Israel: The Technion. Samuel Neaman Institute 2005:7-10.

[53] Canetti D, Waismel-Manor I, Cohen N, Rapaport C. What Does National Resilience Mean in a Democracy? Evidence from the United States and Israel. Armed Forces \& Society. 2013;0095327X12466828.

[54] Lazarus RS, Folkman S. Stress, Appraisal, and Coping. New York, NY: Springer Publishing Company; 1984.

[55] Moos RH, Schaefer J. Coping resources and processes: Current concepts and measures. In: Goldberger L, Breznitz S. editors. Handbook of stress: Theoretical and clinical aspects. 2nd ed. New York: MacMillan; 1993;234-57.

[56] Wolfe J, Keane TM, Kaloupek DG, Mora CA, Wine P. Patterns of positive readjustment in Vietnam combat veterans. Journal of Traumatic Stress 1993;6:179-93.

[57] Glennie EJ. Coping and resilience. Noncognitive skills in the classroom. In: Rosen JA, Glennie EJ, Dalton BW. New perspectives on educational research. Research Triangle Park: RTI International 2010;169-93.

[58] Horesh N, Rolnick T, Iancu I, Dannon P, Lepkifker E, Apter A, Kotler M. Coping styles and suicide risk. Acta Psychiatrica Scandinavica 1996;93:489-93.

[59] Aldwin CM, Revenson TA. Does coping help? A reexamination of the relationship between coping and mental health. Journal of Personality and Social Psychology 1987;53: $337-48$. 
[60] Baker JP, Berenbaum H. Emotional approach and problemfocused coping: A comparison of potentially adaptive strategies. Cognition and Emotion 2007;21:95-118.

[61] Carver CS, Scheier MF, Weintraub JK. Assessing coping strategies: A theoretically based approach. Journal of Personality and Social Psychology 1989;56(2):267-83.

[62] Skinner A, Edge K, Altman J, Sherwood H. Searching for the structure of coping: A review and critique of category systems for classifying ways of coping. Psychological Bulletin 2003;129:216-69.

[63] van den Heuvel SG, van de Vijfeijke H, Leijten FRM, Ybema JF, Robroek SJW, van der Beek AJ, Burdorf A, Taris TW. Health and coping predict work ability: A prospective study on the differential effects of mental and physical health among aging workers. In: Proceedings of Scandinavian Journal of Work, Environment and Health; 2013 August 26-28; Helsinki, Finland. P. 94.

[64] Blanchard-Fields F, Mienaltowski A, Seay RB. Age differences in everyday problems solving effectiveness: Older adults select more effective strategies for interpersonal problems. The Journals of Gerontology, Series B: Psychological Sciences 2007;62B:61-4.

[65] Lazarus RS, Folkman S. The concept of coping. In: Monat A, Lazarus RS, editors. Stress and coping: An anthology. 3rd ed., 189-206. New York: Columbia University Press; 1991.

[66] Day AL, Livingstone, HA. Chronic and acute stressors among military personnel: Do coping styles buffer their negative impact on health? Journal of Occupational Health Psychology 2001;6(4):348-60.

[67] Faller H, Bülzebruck H. Coping and survival in lung cancer: A 10-year follow-up. American Journal of Psychiatry 2002;159(12):2105-7.

[68] Carver CS, Connor-Smith J. Personality and coping. Annual Review of Psychology 2010;61:679-704.

[69] Boerner K. Adaptation to disability among middle-aged and older adults: The role of assimilative and accommodative coping. Journal of Gerontology: Psychological Sciences 2004;59:35-42.

[70] Jonker AA, Comijs HC, Knipscheer KC, Deeg DJ. The role of coping resources on change in well-being during persistent health decline. Journal of Aging and Health 2009;21(8):1063-82.
[71] Diehl M, Chui H, Hay EL, Lumley MA, Grühn D, VabouvieVief G. Change in coping and defense mechanisms across adulthood: Longitudinal findings in a European-American sample. Developmental Psychology 2014;50(2):634-48.

[72] Folkman S, Newman S, Lamb, R, Shipley M. Social relationships and psychological well-being in rheumatoid arthritis. Social Science and Medicine 1986;27:399-403.

[73] Cohn A, Pakenham K. Efficacy of a cognitivebehavioral program to improve psychological adjustment among soldiers in recruit training. Military Medicine 2008;173(12):1151-7.

[74] LeDoux JE, Gorman JM. A call to action: Overcoming anxiety through active coping. Am J Psychiatry 2001;158(12):1953-5.

[75] De Rijk, AE, Le Blanc PM, Schaufeli WB, de Jonge J. Active coping and need for control as moderators of the job demand-control model: Effects on burnout. Journal of Occupational and Organizational Psychology 1998;71:1-18.

[76] Kaiseler M, Queirós C, Passos F, Sousa P. Stress appraisal, coping, and work engagement among police recruits: An exploratory study. Psychological Reports: Employment Psychology \& Marketing 2014;114(2): 635-46.

[77] Bakibinga P, Forbech Vinje H, Mittelmark M. Factors contributing to job engagement in Ugandan nurses and midwives. International Scholarly Research Notices 2012;2012:1-9.

[78] Rothmann S, Jorgensen LI, Hill C. Coping and work engagement in selected South African organizations. SA Journal of Industrial Psychology 2011;37(1):1-11.

[79] Graham JM, Thurston WE. Overcoming adversity: Resilience \& coping mechanisms developed by recent immigrant women living in the inner city of Calgary, Alberta. Women's Health and Urban Life 2005;4(1):63-80.

[80] Ewart CK, Jorgensen RS, Suchday, S, Chen E, Matthews KA. Measuring stress resilience and coping in vulnerable youth: The social competence interview. Psychological Assessment 2002;14(3):339-52.

[81] Kimhi, S, Eshel, Y. Individual and public resilience and coping with long-term outcomes of war. Journal of Applied Biobehavioral Research 2009;14(2):70-89. 